\title{
Chemical and Microbiological Evaluation of Pasteurized Milk Available in Sylhet City of Bangladesh
}

\author{
S. Saha* and A. Ara \\ Dept. of Dairy and Poultry Science, Sylhet Agricultural University, Sylhet-3100, Bangladesh \\ *Corresponding author and Email: sudeb.sau@gmail.com
}

Received: 29 May 2012

Accepted: 15 November 2012

\begin{abstract}
A study was conducted to evaluate the chemical and microbiological quality of pasteurized milk samples belonging to five brands: Milk vita, Tatka, Farm Fresh, Aarong and RD milk. Pasteurized milk of different brands were collected from the retail store of Sylhet city and the laboratory examination was conducted at Dairy Science Laboratory under the Dept. of Dairy and Poultry Science, Sylhet Agricultural University, Bangladesh during January to march 2012. The average fat contents were 3.51, 3.06, 3.26, 3.41 and 3.33 for Milk vita, Tatka, Farm Fresh, Aarong and RD milk brands respectively. There was significant difference among the different brands pasteurized milk in respect of fat $\%$. The protein contents were 4.07, 4.14, 4.14, 4.03 and 4.10 respectively in Milk vita, Tatka, Farm Fresh, Aarong and RD milk brands, though the difference was not significant. The equivalent SNF contents were $8.13,8.54,8.15,8.11$ and $8.02 \%$, whereas total solids were $11.46,11.58,11.41,11.53$ and $11.35 \%$, respectively. Acidity content of different brands of pasteurized milk was highly significant $(p<0.001)$. The standard plate counts were significantly $(p<0.001)$ different while coliform counts were similar among the different brands of pasteurized milk. It was found that the Milk vita brand pasteurized milk maintained standard levels for chemical composition and microbiological quality because it follow the BSTI (2002) as per as possible.
\end{abstract}

\section{Keywords: Pasteurized milk, chemical quality, microbiological quality}

\section{Introduction}

Milk is an indispensable food for human being from infancy to old age. It contains all the nutrients necessary for health in almost ideal proportion. So, it is considered as nature's single most complete food (O'Mahony, 1988). Milk contains all nutrients but during heating, some of the enzymes are destroyed which are essential for the absorption of calcium and vitamin D.

Pasteurization is a heating process to prevent the spoilage of milk. Pasteurization has been used since the early 1900 s (heating raw milk to $161^{\circ} \mathrm{F}$ for 15 minutes) is expected to remove microorganisms from milk (Imele et al., 2002). Milk may be contaminated by the microbial agents during processing, transportation, storage and preparation of milk products for consumption. Microbes have access to milk to reproduce at a rapid rate. Pasteurization is done for the improvement of keeping quality of milk. The purpose of chemical and microbial quality control carried out by the government inspection service is to provide good and safe food for human consumption. Due to the nonenforcement of Milk Inspection Act, consumers are deprived of getting quality milk. Due to wide 
spread consumption by infants, children and adults, milk has been marked as the most important food for which chemical and microbial quality control should be attained. Staphylocooci may come into milk and milk product from food handlers (Pelczar et al., 1965). There is no study conducted on pasteurize milk marketed in Sylhet region. However, such study would be helpful to formulate suggestive measures to improve the quality of pasteurized milk. The objectives of the study were to: assess the quality of pasteurized milk marketed in Sylhet City and to determine the chemical composition and the presence of microbial population in the samples obtained from different brands of milk.

\section{Materials and Methods}

The commercially packaged pasteurized milk was collected from retail stores of local markets situated in the city of Sylhet during January to March 2012 and analysis was conducted at the Dairy Science Laboratory of Dairy and Poultry Science department, Sylhet Agricultural University, Bangladesh. Samples of five different brands of commercial pasteurized milk were selected for the study. These brands belonged to Milk vita, Tatka, Farm Fresh, Aarong and RD Milk. The following chemical and microbial tests were performed on the milk samples:

Chemical tests: a) Fat content, b) Solids-not-fat content, c) Total solids content, d) Protein content and e) Acidity percentage.

Microbiological tests: a) Standard Plate Count and b) Coli form count.

Prior to taking samples, the packets were shaken thoroughly for proper mixing of the pasteurized milk. The sample packets were opened with the help of sterile scissor. The percentage of fat in milk samples was determined by the Gerber fat test method (Goss, 1953). Total solids of the milk samples were determined by oven drying method as described by AOAC (2003). The SNF content and total solids contents were estimated using the Gerber method. Protein was determined by formol titration method (Bennenberg et al., 1949). Acidity percentage was determined by titration method according to Aggarwala and Sharma (1961). For the assessment of microbiological quality of milk, Standard Plate Count (SPC) and Coliform Counts were performed according to American Public Health Association (APHA, 1998), using plate count agar for SPC and EMB agar for Coliform count. Statistical analysis was done using computer program Minitab as per Khan and Chaudhry (2010) by following Completely Randomized Design (CRD).

\section{Results and Discussion}

\subsection{Chemical quality}

Table 1 shows that the average values of fat content observed for the five brands pasteurized milk were generally below the minimum level of $3.5 \%$. The BSTI (2002) requirement for fat content of pasteurized milk is a minimum of $3.5 \%$ which was fulfilled by only one Milk vita brand. Tatka had the lowest level of fat (3.06). Statistical analysis has shown that there were significant differences among the fat content levels of different brands of pasteurized milk. The reduction of fat level in the pasteurized milk may be the result of starting milk with a lower than normal fat level (Santos and Fonseca, 2000) or may also be caused by the withdrawal of fat from the original milk that were used for pasteurization.

The Food and Drug Administration (FDA) standard for Solids not fat (SNF) content of milk is a minimum of $8.25 \%$ (Graf, 1976). The SNF contents in the sample pasteurized milk, except Tatka did not maintain the BSTI (2002) requirement. However, all the brands had the above $8.0 \%$ SNF contents. The highest SNF content was $8.54 \%$ found in Tatka and the lowest was $8.02 \%$ in RD Milk brand. There was significant differences $(\mathrm{p}<0.01)$ in solids not fat contents among different brands of pasteurized milk. Addition of water dilutes milk reducing its total solids content. Total solids contents of 10.5 to $14.5 \%$ was reported by O'Mahony (1988). 
Table 1. Comparisons of chemical composition of different brands of pasteurized milk

\begin{tabular}{lccccc}
\hline Brand & Fat\% & Protein\% & SNF\% & TS\% & Acidity\% \\
\hline Milk vita & $3.51^{\mathrm{a}}$ & 4.07 & $8.13^{\mathrm{b}}$ & 11.46 & $0.166^{\mathrm{ab}}$ \\
Tatka & $3.06^{\mathrm{b}}$ & 4.14 & $8.54^{\mathrm{a}}$ & 11.58 & $0.136^{\mathrm{c}}$ \\
Farm Fresh & $3.26^{\mathrm{ab}}$ & 4.14 & $8.15^{\mathrm{b}}$ & 11.41 & $0.141^{\mathrm{c}}$ \\
Aarong & $3.41^{\mathrm{a}}$ & 4.03 & $8.11^{\mathrm{b}}$ & 11.53 & $0.157^{\mathrm{b}}$ \\
RD milk & $3.33^{\mathrm{ab}}$ & 4.10 & $8.02^{\mathrm{b}}$ & 11.35 & $0.169^{\mathrm{a}}$ \\
LSD & 0.05 & 0.173 & 0.375 & 0.467 & 0.011 \\
\hline Signf. level & $* *$ & $\mathrm{NS}$ & $* *$ & $\mathrm{NS}$ & $* * *$ \\
\hline
\end{tabular}

$\mathrm{NB}: * * *=$ Significant level at $0.1 \%$ level, $* *=$ Significant level at $1 \%$ level, NS= Insignificant

Table 2. Comparisons of microbiological quality of different brands of pasteurized milk

\begin{tabular}{lcc}
\hline Brand & $\mathrm{SPC}(\mathrm{cfu} / \mathrm{ml}) \times 10^{4}$ & Coliform(cfu/ml) \\
\hline Milk vita & $5.4^{\mathrm{c}}$ & 10.00 \\
Tatka & $5.3^{\mathrm{c}}$ & 12.80 \\
Farm Fresh & $6.3^{\mathrm{b}}$ & 14.40 \\
Aarong & $6.4^{\mathrm{b}}$ & 15.00 \\
RD Milk & $6.8^{\mathrm{a}}$ & 13.40 \\
LSD $_{0.05}$ & 0.38 & 3.55 \\
\hline Significance level & $* * *$ & $\mathrm{NS}$ \\
\hline
\end{tabular}

NB: $* * *=$ Significant level at $0.1 \%$ level, $\quad$ NS= Insignificant

The protein content of cows milk has been reported to vary from $3.22 \%$ to $3.92 \%$ (Ramasamy et al.,1999, Lingathurai et al., 2009) and $3.77 \%$. The protein contents of the five pasteurized brands milk (above $4 \%$ ) were within the acceptable limit according to BSTI (2002) standard (not lower than 3.3\%). However, the differences among the protein contents of five brands of pasteurized milk samples were insignificant. Ghani and Rahman (1954) reported the fat content in native cows milk was $5.4 \%$, which was higher than that of standard level. On the other hand, protein content was below than that of PFA (Prevention of Food Adulteration) 
level. Protein content of cow's milk varies from $3.07 \%$ to $3.57 \%$ in Bangladesh according to Hossain et al. (2011) which is below than standard level. Therefore, to maintain the standard level milk marketing companies add extra protein in their milk which might have caused higher protein level in the investigated pasteurized milk of the present study.

Acidity percentage is a measure of freshness and bacterial activity in milk. Popescu and Angel (2009) reported that high quality milk must have acidity of less than 0.14 percent. The acidity percentage of the pasteurized milks ranged from 0.136 to $0.169 \%$, where as BSTI (2002) allows a maximum acidity content of $0.15 \%$ for the pasteurized milk. The highest value was $0.169 \%$ found in RD Milk indicating high bacterial activity and the lowest was $0.132 \%$ in TATKA indicating it's relatively better quality with regards to freshness. There was highly significant difference $(\mathrm{p}<0.001)$ among the different brands of pasteurized milk in respect of acidity. Elmagli and El Zubeir (2006) observed a greater range of acidity ( 0.14 to $0.86 \%)$ in pasteurized milks. Acidity of all the brands of pasteurize milk was within the range reported by Elmagli and El Zubeir (2006). Determination of acid in milk is an important factor in judging milk quality. Acidity also affects taste as well. Increase in acidity of milk might be due to the rough measure of its age and bacterial activity (O'Mahony, 1988). The degree of bacterial contamination and the temperature at which the milk is kept are the main factors influencing acid formation (Hossain et al., 2011).

\subsection{Microbiological quality}

The standard plate count (SPC) of the pasteurized milk samples ranged from 54200 to $68400 \mathrm{cfu} / \mathrm{ml}$, which is much higher than that recommended by BSTI and USPHS (not exceeding 20,000 cfu/ml) (BSTI, 2002; Jay, 2003). Table 2 shows that the pasteurized milk samples of Milk vita brand were good quality than other brands. The reason for high bacterial count in the pasteurized milks might include defective pasteurization machinery, surviving pasteurization, and post-pasteurized contamination due to poor processing and handling conditions and/or poor hygienic practices by the concerned employees. Anderson and Stone (1955) also remarked that pasteurized milk might be contaminated due to poor bacteriological quality of milk and inadequate plant cleanliness.

Coliforms are considered as 'indicator organisms' because their presence in food indicates some form of contamination. The present study has shown the highest coliform counts in Aarong brand. The presence of large numbers of coliform in foods is highly undesirable. The coliform standard for "grade a" milk should not exceed $10 \mathrm{cfu} / \mathrm{ml}$ (Frazier and Westhoft, 1958). All the brands of pasteurized milk, except Milk vita had coliform counts higher than $10 \mathrm{cfu} / \mathrm{ml}$. However, the differences among the five brands of pasteurize milk were not significant in respect of coliform.

\section{Conclusions}

Milk vita brand had less number of bacterial counts than the other brands of pasteurized milk. The hygienic measurements of pasteurized milk were very poor. All pasteurized milk samples had high bacterial population and some contained pathogenic bacteria. Although coliform is the index of sanitary quality but all the pasteurized samples exceed the standard level $(10 \mathrm{cfu} / \mathrm{ml})$ except Milk vita. Fat content was below the standard in all samples except Milk vita. The presence of pathogenic organisms is harmful to human health. Therefore frequent inspection of the marketed milk should be carried out to check whether they meet the minimum legal standards. The overall hygienic conditions surrounding the production and handling of milk should also be monitored. From the above findings it may be concluded that only Milk vita brand pasteurized milk maintained satisfactory standard in respect of chemical composition and microbiological quality. 


\section{References}

Aggarwal, A. C. and Sharma, 1961. A Laboratory Manual of Milk Inspection. 4th edn., Asia the Publishing House, Bombay, Calcutta, New Delhi, India. 14 p.

Anderson, B. H. and Stone, D. M. 1955. Staphylococcal food poisoning associated with spray dried milk. Journal of Hygiene, 53: 783-797.

AOAC. 2003. Official Methods of Analysis of the Association of Agricultural Chemists, $17^{\text {th }}$ edn., Washington, USA, 990.19 p.

APHA (American Public Health Association). 1998. Standard Methods for examination of Dairy Products, $20^{\text {th }}$ edn., Washington D.C. USA, 144 and 147-148 pp.

Bennenberg, H. J., Hock, C. and Vandan, W. 1949. Estimation of milk protein by formol titration. Dairy Science Abstract, 45:103.

BSTI. 2002. BDS 1702: 2002. Bangladesh Standard: Specification for Pasteurized Milk. Bangladesh Standards and Testing Institution, Tejgaon Industrial Area, Dhaka, 2-3 pp.

Elmagli, A. A. O. and El Zubeir, E. L. 2006 Study on the compositional quality of pasteurized milk in Khartoum State (Sudan). International Journal of Dairy Sciences, 1 (1): 12-20.

Frazier, W. C. and Westhoff, D. C. 1958. Pasteurized milk in milk Ordinance and Code (US PHS) Food Microbiology. $1^{\text {st }}$ edn. Mc Graw Hill Inc. New Delhi, 112 p.

Ghani, M. O. and Rahman A. F. M. 1954. Composition of cow milk in East Bengal and the presumptive standard for milk. Pakistan Journal of Science, 6: 203-206.

Goss, E. F. 1953. Techniques of dairy testing Ames (lowa). The lowa State College Press, US, $350 \mathrm{p}$.

Graf, T. F. 1976. Market implications of changing fat content of milk and dairy products, fat content and composition of animal products. Proceedings of $a$ symposium, board on agriculture and renewable resources. BARR, CNR, FNB, $A L S$ and NRC, $1^{\text {st }}$ edn. National Academic Press, USA, 189-190 pp.

Hossain, T. J., Alam, M. K., Sikdar, D. (2011). Chemical and Microbiological quality assessment of raw and processed liquid market milks of Bangladesh. Continental Journal of Food Science and Technology, 5 (2): $6-17$.

Imele, H., Kamage, A. and Mendi, S. 2002. Effect of pasteurization temperature on the total milk flora. Animal Health and Production in Africa, 48 (3): 177-181.

Jay, J. M. 2003. Modern Food Microbiology,. $4^{\text {th }}$ edn., CBS Publishers \& Distributors, New Delhi, 447 p.

Khan, M. M. H. and Chaudhry, A. S. 2010. Chemical composition of selected forages and spices and the effect of these spices on in vitro rumen degradability of some forages. Asian-Australian Journal of Animal Sciences, 23(7): 889-900.

O'Mahony, F. 1988. Rural dairy technology: Experiences in Ethiopia. International Livestock Centre for Africa, Addis Ababa, Ethiopia. ILCA Manual No. 4, Dairy Technology Unit, 3\& 8 pp.

Pelczar, J., Michael, J. R. and Roger, D. R 1965. Microbilology, $2^{\text {nd }}$ edn., McGraw Hill, US, $132 \mathrm{p}$.

Popescu, A. and Angel, E. 2009. Analysis of milk quality and its importance for milk processors. Lucrări Ştiinţifice Zootehnie Şi Biotehnologii, Timisoara, 42 (1): 501503.

Ramasamy, D., Shibu, A. V., and Gopi, H. 1999. Dairy Technologist's Handbook, $1^{\text {st }}$ edn., International Book Distributing Company, Delhi, India, 27 p.

Santos, M. V. and Fonseca, L. F. L. 2000. Qualidade do Leite e Controle de Mastite, Sa o Paulo: Lemos Editorial, 175 p. 